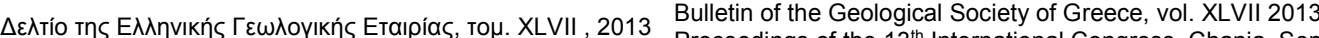

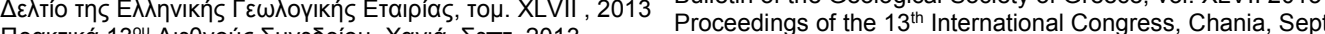

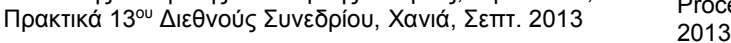

\title{
COAL DEPOSITS OF TURKEY: PROPERTIES AND IMPORTANCE ON ENERGY DEMAND
}

\author{
Oskay R.G. ${ }^{1}$, Inaner H. ${ }^{2}$, Karayigit A.I. ${ }^{3}$ and Christanis K. ${ }^{1}$ \\ ${ }^{1}$ University of Patras, Department of Geology, Rio-Patras, Greece,oskay@upatras.gr, \\ christan@upatras.gr \\ ${ }^{2}$ Dokuz Eylül University, Department of Geological Engineering, İzmir, Turkey \\ ${ }^{3}$ Hacettepe University, Department of Geological Engineering, Ankara, Turkey
}

\begin{abstract}
In the last two decades electricity generation and consumption in Turkey was increasing steadily. Around $80 \%$ of the electricity generated is derived from fossil fuels such as imported natural gas and oil, and domestic coal. As the energy policy now is focusing on reducing the dependency on imported fuels, coal, particularly this of low-rank, is becoming important for the country. Latest explorations showed that total coal reserves of Turkey reach to $13 \mathrm{Gt}$ with low-rank coals (i.e. lignite and sub-bituminous) being dominant. Coal deposits, formed under various conditions and in various geological times, are widely spread over the territory. The most significant deposits are of Tertiary, especially Neogene age. Neogene coals are most appropriate for combustion in the thermal power plants due to the high total reserves despite the high ash yields and the low calorific values. We imply that applying reasonable exploitation planning and appropriate washing techniques, coal will play a key role in future energy supply of the country.

Key words: Low-rank coal, Neogene, coal-bearing basin, thermal power plants
\end{abstract}

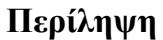

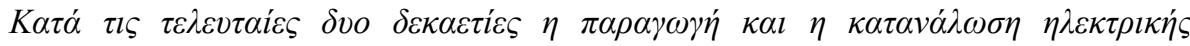

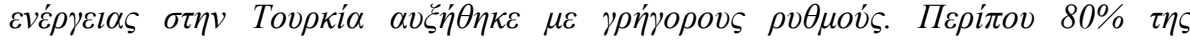

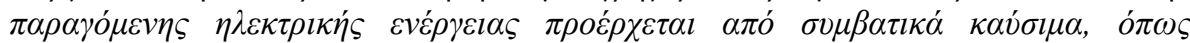

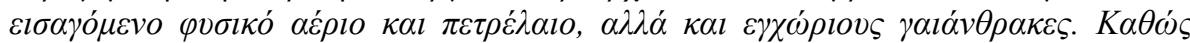

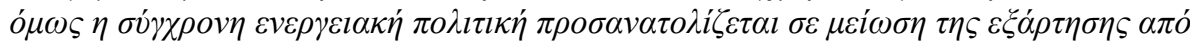

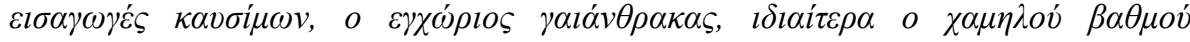

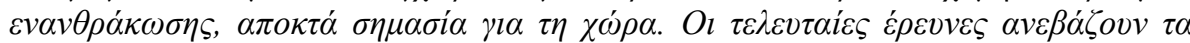

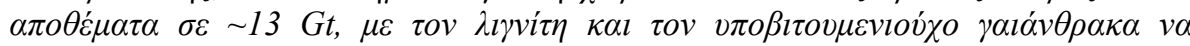

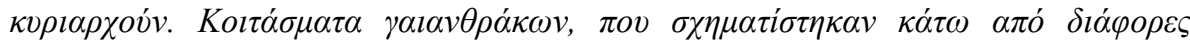

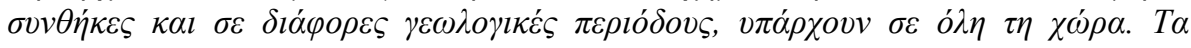

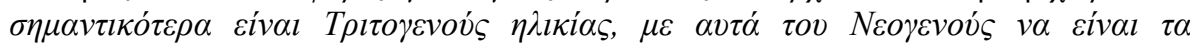

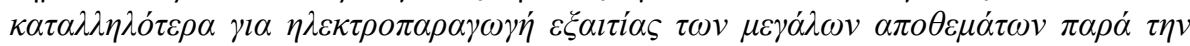

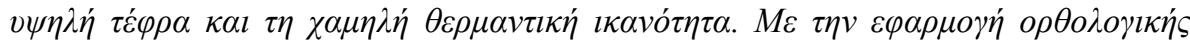

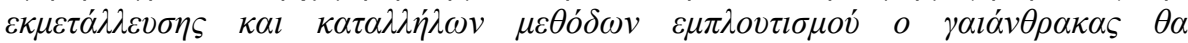

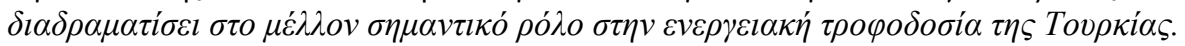

$\underline{\text { XLVII, No } 3-2111}$ 


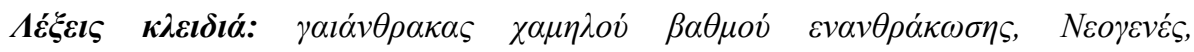

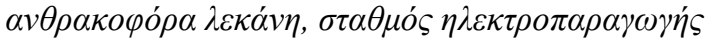

\section{Introduction}

In the last two decades electricity demand in Turkey was increasing steadily from $128 \mathrm{TWh}$ in 2000 to 209 TWh in 2010, with an $8 \%$ increase per year, on average, due to industrial development and economic growth (Lynch, 2003; EÜAŞ, 2004, 2011). Around 80\% of the electricity generated is derived from fossil fuels such as imported natural gas and oil, and domestic coal. To support the increasing demand, several natural gas-fired power plants were constructed as electricity generation from natural gas used to be cheaper and cleaner than from the domestic coals (EÜAŞ, 2004; Yilmaz and Uslu, 2007; Biresselioğlu et al., 2012). However, the rapid increase of oil price and some problems in natural gas supply (Biresselioğlu et al., 2012; Ekşi et al., 2012), led the Turkish energy policy to focus on domestic energy sources such as coal, as well as on renewable sources (wind, geothermal and solar energy) (MENR, 2004; Melikoğlu, 2013).

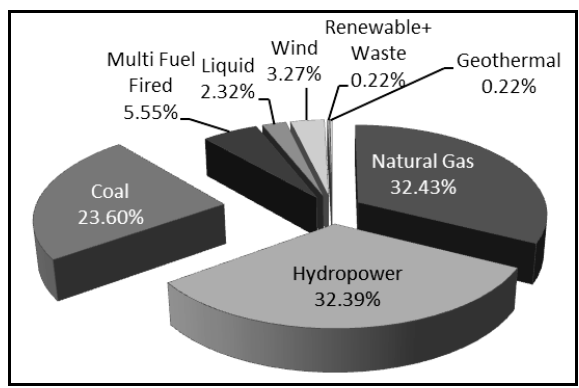

Figure 1 - Share of the sources of Turkey's installed capacity for power generation (from EÜAŞ, 2011)

Even though Turkey does not own enough natural gas reserves to support demand, about $33 \%$ of the installed capacity is based on power plants mostly supplied by imported natural gas (Figure 1, Tables 1, 2). Domestic oil and gas reserves are located in SE Turkey and on Thrace Peninsula, whereas some gas reserves are recently discovered off-shore in western Black Sea (TPAO, 2011).

Table 1 - Installed capacity of Turkey's Electricity Generation System by Primary Source (simplified from EÜAŞ, 2011); *: not available data

\begin{tabular}{|l|c|c|c|c|}
\hline \multicolumn{1}{|c|}{ Source } & \multicolumn{2}{c|}{ Installed Capacity* } & \multicolumn{2}{c|}{$\begin{array}{c}\text { Power Generation } \\
\text { (TWh) }\end{array}$} \\
& $(\mathbf{M W})$ & $\mathbf{( \% )}$ & \multicolumn{1}{c|}{$(\mathbf{\% )}$} \\
\hline Natural Gas & 17,159 & 32.43 & 104.04 & 45.36 \\
\hline Hydropower & 17,137 & 32.39 & 52.34 & 22.82 \\
\hline Coal (lignite + subbit. \& bit. coal + asphaltite) & 12,491 & 23.60 & 66.22 & 28.87 \\
\hline Multi Fuels (diesel and natural gas) & 2,936 & 5.55 & $*$ & $*$ \\
\hline Wind & 1,729 & 3.27 & 4.72 & 2.06 \\
\hline Liquid Fuels (e.g. diesel oil etc.) & 1,229 & 2.32 & 0.90 & 0.39 \\
\hline Renewable + Waste & 115 & 0.22 & 0.46 & 0.20 \\
\hline Geothermal & 114 & 0.22 & 0.69 & 0.30 \\
\hline Total & $\mathbf{5 2 , 9 1 1}$ & $\mathbf{1 0 0 . 0 0}$ & $\mathbf{2 2 9 . 4 0}$ & $\mathbf{1 0 0 . 0 0}$ \\
\hline
\end{tabular}

Table 2 - Installed capacity and power generation based on coal (simplified from EÜAŞ, 2011)

\begin{tabular}{|l|c|c|}
\hline \multicolumn{1}{|c|}{ Resources } & Installed capacity (MW) & Generation (TWh) \\
\hline Lignite + subbituminous coal & 8,140 & 38.87 \\
\hline Bituminous coal & 300 & 2.00 \\
\hline Imported coal + asphaltite & 4,051 & 25.34 \\
\hline
\end{tabular}

$\underline{\text { XLVII, No } 3-2112}$ 
Recent studies indicate that Turkey has a great potential of renewable energy resources like solar, wind and geothermal energy (MENR, 2004; Demirbaş, 2006; EÜAŞ, 2011; Melikoğlu, 2013); on the other hand, the exploitation of the coal resources seems to be more advantageous than this of the renewable ones. The main reason is that several economic coal deposits suitable for electricity generation are, in general, located close to the capital city and some industrial cities (e.g. Çayırhan/Ankara; Orhaneli/Bursa; Karapınar/Konya; Figure 2). The average power generation cost from lignite is also low (c. US\$ 0.014 per kWh; Kıncay and Öztürk, 2003; Kocaoğlu, 2009). Recent coal explorations imply that low rank coals will be the most important domestic energy source for the next decades in Turkey (MTA, 2010; EÜAŞ, 2011).

There are also other alternative hydrocarbon resources in Turkey (Figure 2), which are of minor utilisation capacity such as asphaltite (Karayiğit and Querol, 2002) and bituminous shale (Kok, 2010), whereas non-economic oil sand outcrops also occur (Taşman, 1950). Peatlands are not exploited for energy purposes, but for using peat in horticulture and agriculture only (İnaner and Nakoman, 2004).

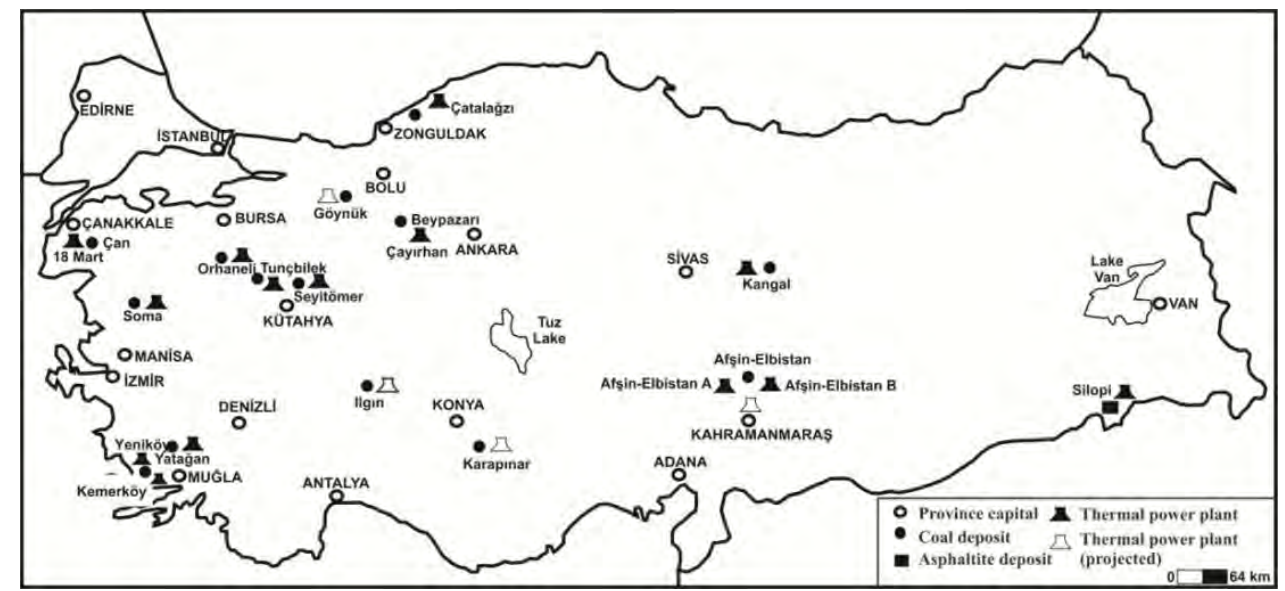

Figure 2 - Coal-fired thermal power plants and supporting coal deposits in Turkey (modified from İnaner and Nakoman, 2004; MTA, 2010; Şengüler, 2010; EÜAŞ, 2011; Parkmaden, 2012)

The coal deposits, especially the lignite ones, have been studied by several researchers with various aims and scopes (Ünalan, 2010); however, there is no comparable study till now. The aim of this paper is to review the distribution, quality and reserves of Turkish coal deposits by compiling results of previous studies.

\section{Coal-bearing basins}

Coal-bearing basins are widely distributed throughout the country (Figure 3); they formed under variable tectonic regimes during geological times, and thus the basins show various features (arcrelated, epirogenic, rift, 'ova' basin, etc.). Several researchers categorize the coal deposits according to the coal age, features, rank, utilization etc. Age categorization seems to be the most suitable due to structural differences of the basins within the same geographic region and hence, genetic and quality variations of the hosted coal deposits.

The coal-bearing basins formed mainly during Palaeozoic and Cenozoic eras (İnaner and Nakoman, 1997; Tuncali et al., 2002; Palmer et al., 2004; Besbelli, 2009; Toprak, 2009), whereas during Mesozoic the palaeoenvironmental conditions favoured carbonate-platform deposition with terrestrial regime being limited; a few Mesozoic coal deposits were locally formed in eastern Pontides (NE Turkey) and eastern Taurides (Mann et al., 1998; Ünalan, 2003; Korkmaz and KaraGülbay, 2007). 


\subsection{Palaeozoic Coals}

The Zonguldak coal deposits (Figure 3) of Namurian to Westphalian D age were formed in a progradational delta and flood plain environment (Akgün and Akyol, 1992; Karayiğit et al., 1998). The deposits were affected by palaeotectonic events (Hercynian orogenic movements) resulting in overlapped seams in the basin (Okay et al., 1994; Karayiğit et al., 1998, 2000). The calorific values of Zonguldak coal are on average $6600 \mathrm{kcal} / \mathrm{kg}$ (on air-dry basis); coal displays low sulphur (avg. $0.77 \%$, on air-dry basis) and volatile matter contents (avg. 42.49\%, on dry, ash-free basis), and low ash yield $(8.27 \%$, on dry basis) (Karayiğit et al., 1998; 2000). Other Palaeozoic coal deposits (Figure 3), were locally formed around Kemer (Pamucak and Çukurboy)/S Turkey and Hazro/SE Turkey; they have no economic importance (Ünalan, 2003; İnaner and Nakoman, 2004).

\subsection{Mesozoic Coals}

As already mentioned, the Mesozoic was not suitable for coal formation in Turkey. The Mesozoic (mainly Jurassic) coal deposits at Feke and Kozan/Adana, Norsun and Gödül-Alansa/Gümüşhane have no economic significance. They are of sub-bituminous (Feke, Alansa) to bituminous rank (Kozan, Norsun, Gödül) and display low moisture (avg. 4.70\%, as-received basis) and high ash yields (avg. 38.70\%, dry basis). All Jurassic coals are deposited under marine-influenced telmatic conditions (Mann et al., 1998; Korkmaz and Kara-Gülbay, 2007).

\subsection{Cenozoic Coals}

During Cenozoic, especially in Southern and Western Turkey, several sedimentary basins (e.g. rift or foreland basins) were formed in a range of tectonic (compressional, extensional and strike-slip) settings, hosting coal-bearing sequences with large reserves (Şengör and Y1lmaz, 1981; Görür et al., 1997; Kelling et al., 2005; Toprak, 2009). The Cenozoic coal deposits formed in paralic and/or limnic environments, and consist mostly of lignite and sub-bituminous coals (Gökmen et al., 1993; İnaner and Nakoman, 1997; Tuncali et al., 2002; Palmer et al., 2004). Shallow marine-influenced coal deposits generally formed during Palaeogene, while terrestrial conditions (limnic, continental with volcanic intercalations, fluvial, deltaic) were common during Neogene times (Palmer et al., 2004).

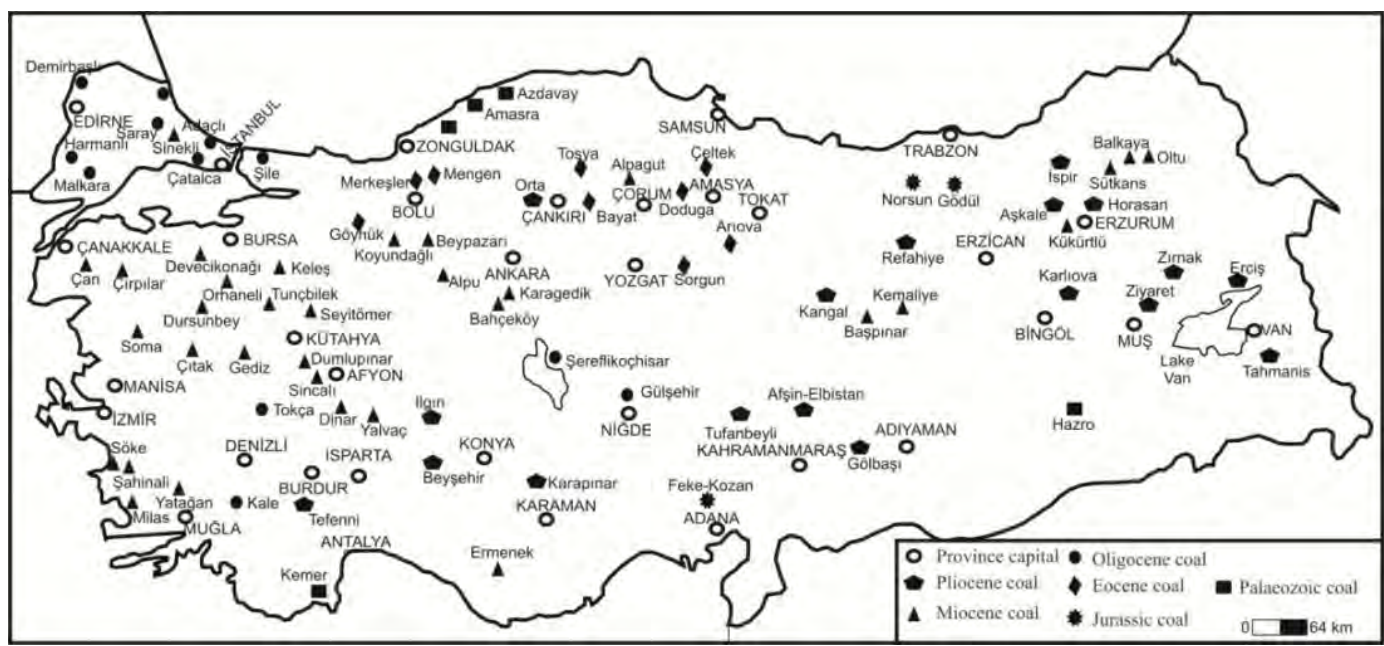

Figure 3 - Important coal deposits of Turkey (modified from İnaner and Nakoman, 2004; MTA, 2010)

\subsubsection{Palaeogene Coals}

Palaeogene coal-bearing basins formed in foreland basins between Upper Eocene and Oligocene (Görür et al., 1997). Eocene coal-bearing basins are mostly located in central part of the western 
Black Sea region (Mengen and Merkeşler/Bolu; Dodurga and Alpagut/Çorum); whereas Sorgun/Yozgat is located in north-eastern Central Turkey (Gökmen et al., 1993; İnaner and Nakoman, 1997; Toprak, 2009). The sedimentary fillings of these basins consist of terrestrial and/or shallow marine sediments. The coal-bearing sequences are intercalated with marl, crossbedded conglomerate, and sandstone. The basement consists generally of Mesozoic crystalline rocks such as marble, schist, gneiss (Erdoğan et al., 1996; Görür et al., 1997; İnaner and Nakoman, 1997; Palmer et al., 2004; Akkiraz et al., 2008). All Eocene coals are of subbituminous rank, and display (on average, as-received basis) low moisture (11.19\%), moderate ash yield (28.18\%), high total sulphur content $(5.13 \%)$, high calorific values $(4050 \mathrm{kcal} / \mathrm{kg}$ ) and fixed carbon content (avg. 55\%, dry, ash-free basis) (İnaner and Nakoman, 1997; Karayiğit and Whateley, 1997; Tuncali et al., 2002, Besbelli, 2009; Toprak, 2009). Although the all the Eocene geological reserves are low $(629 \mathrm{Mt})$, the rank is higher and the quality better than these of other Tertiary low-rank coals in the country (Gökmen et al., 1993; İnaner and Nakoman, 1997).

Oligocene and Oligocene/Miocene coal-bearing basins are mainly located on Thrace Peninsula such as Uzunköprü, Harmanlı and Vize/Edirne, Saray and Malkara/Tekirdağ, Şile/İstanbul and also in Southwestern (Kale/Denizli; Çardak and Tokça/Burdur) and Central Turkey (Şereflikoçhisar/Ankara). They generally formed in paralic (fluvial-delta) environments (İnaner and Nakoman, 1997; Tuncali et al., 2002; Besbelli, 2009). During Early-Middle Oligocene coalbearing deposits on Thrace Peninsula formed in limnic-fluvial and paralic environments. Furthermore, lacustrine-fluvial and molasse facies are typical for SW Turkey during Late Oligocene and coal-bearing sediments are generally hosted within molasse facies (Akgün and Sözbilir, 2001; Palmer et al., 2004; Akgün and Akkiraz, 2005; Sözbilir, 2005). The Oligocene geological reserves amount to around $1 \mathrm{Gt}$ (Besbelli, 2009) but the quality is poorer than this of the Eocene coals. They are of subbituminous rank with high ash yield and moisture (on avg. $25 \%$ and $32 \%$, respectively). The net calorific value is $2500 \mathrm{kcal} / \mathrm{kg}$ (on avg., as-received basis) (Innaner and Nakoman, 1997; Karayiğit and Whateley, 1997; Tuncali et al., 2002; Besbelli, 2009; Toprak, 2009).

\subsubsection{Neogene Coals}

Significant coal formation took place during Neogene times (between Middle Miocene to Pliocene). Within the onset of Miocene terrestrial conditions dominated over the greatest part of the territory. The formation of the major coal-bearing basins and the activation of volcanoes in Western Turkey such as in Çan/Çanakkale, Soma/Manisa, Bigadiç/Balıkesir, Orhaneli/Bursa, Seyitömer/Kütahya and Yatağan/Muğla, took generally place due to extensional tectonics (Ediger, 1990; Ercan et al., 1996; Görür et al., 1997; Akgün and Akyol, 1999; Bozkurt and Sözbilir, 2004; Akkiraz et al., 2011). In Eastern Turkey the coal-bearing basins are strike slip-related (Gölbaşı/Adıyaman; Karlıova/Bingöl), intermontane (Muş and Adilceviz/Bitlis; Pasinler/ Erzurum); in Central Turkey they are 'ova' (Afşin-Elbistan/Kahramanmaraş; Kangal/Sivas; Ulukışla/Niğde; Ilgın/Konya) or epirogenic (Alpagut/Çorum; Şarkışla/Sivas; Refahiye/Erzincan) (Şengör et al., 1984; Görür et al., 1997; Karayiğit and Whateley, 1997; Kayseri and Akgün, 2008; Besbelli, 2009; Toprak, 2009).

The basement of the Miocene coal-bearing basins generally consists of Palaeozoic and/or Mesozoic metamorphic and carbonates rocks. The coal-bearing sequences consist of conglomerate, sandstone, silty claystone and are overlain by marl, lacustrine limestone, tuff and/or basaltic lava and andesite. They usually contain one or two seams with variable thicknesses ranging from 1 to $25 \mathrm{~m}$ (Görür et al., 1997; İnaner and Nakoman, 1997). Miocene coals such as at Seyitömer/Kütahya,Yatağan/Muğla and Beypazarı/Ankara, are of lignite rank, and at Tunçbilek/Kütahya, Soma/Manisa, Ermenek/Karaman and Çan/Çanakkale, of subbituminous rank. There are additionally two Miocene coal deposits namely these of Gökler/Gediz and Aşkale/Erzurum, which were heat affected by nearby volcanic activity and reached the rank of bituminous coal; this effect caused also enrichment in Sb, (Karayiğit and Whateley, 1997; Toprak, 
2009). The total Miocene lignite reserves amount to approximately 4 Gt (Besbelli, 2009) of variable quality and calorific values (from $1300 \mathrm{kcal} / \mathrm{kg}$ to $4500 \mathrm{kcal} / \mathrm{kg}$, on as-received basis).

During Pliocene limnic-fluvial and volcanic-limnic deposits widely formed in Central Anatolia (around Konya, Sivas), SE parts of South Anatolia (Adana, Kahramanmaraş-Afşin-Elbistan) and Eastern Anatolia (Erzurum, Bingöl, Adıyaman) (İnaner and Nakoman, 1997; Palmer et al., 2004; Toprak, 2009). The basement consists of Palaeozoic or Mesozoic rocks and the coal-bearing sequences include pebblestone, sandstone, sandy-silty claystone and marl. These series are generally overlain by marl and/or volcanic rocks (andesite, basalt, and tuff). They host one or two coal seams with variable thickness, up to $100 \mathrm{~m}$ (Gökmen et al., 1993; İnaner and Nakoman, 1997; MTA, 2010). The total Pliocene reserves are large (7 Gt); two important coal deposits belong to this group, namely these of Afşin-Elbistan Basin (4 Gt) in Kahramanmaraş, Southern Turkey, and of Karapinar-Ayrancı Basin (1.8 Gt) in Konya, Central Turkey. The latter is recently discovered and explored (MTA, 2010; Salman, 2010). Other important Pliocene coal deposits are located in Beyşehir-Seydişehir/Konya (422 Mt), Tufanbeyli/Adana (400 Mt), Kangal/Sivas (220 Mt), Orta/Çankırı (123 Mt), Karlıva/Bingöl (105 Mt); small deposits are these at Gölbaşı/Adiyaman, Ilgın/Konya and Ispir, Erciş, Horasan/Erzurum (İnaner and Nakoman, 1997; Besbelli, 2009; Toprak, 2009; MTA, 2010). The Pliocene coals are of lignite rank and display (on as-received basis) high moisture (25.31-53.42\%) and ash yield (11.38-36.37\%), and low calorific values ranging from 1100 to $2200 \mathrm{kcal} / \mathrm{kg}$ (Gökmen et al., 1993; İnaner and Nakoman, 1997; Palmer et al., 2004; MTA, 2010).

\section{Coal Reserves}

The coal exploration in Turkey begun in late $19^{\text {th }}$ century; the first discovery in Zonguldak is dated back to 1848 (Can et al., 2012). The main exploration was carried out between 1950s and 1970s (Lüttig, 1968; Gold and Lüttig, 1972; Yilmaz and Uslu, 2007). Based on the 1990s studies the total coal reserves in Turkey were estimated to around 9.4 Gt (Tuncali et al., 2002; Ünalan, 2003), placing Turkey at the seventh place worldwide (Tuncali et al., 2002). Most of the reserves correspond mainly to low-rank (lignite and sub-bituminous) coals. The total reserves of bituminous coal amount to $1.4 \mathrm{Gt}$ (TKK, 2009). Lignite displays low calorific values $(<2000$ $\mathrm{kcal} / \mathrm{kg}$ ) and only $6 \%$ of the reserves have $>3000 \mathrm{kcal} / \mathrm{kg}$ (Figure 4; İnaner and Nakoman, 1995; Ersoy, 2003; EÜAŞ, 2011). The Pliocene basins host the highest share $(60 \%)$ of the total lignite reserves (Figure 4); Afş̧in-Elbistan and Karapınar-Ayrancı deposits with $4 \mathrm{Gt}$ and $1.8 \mathrm{Gt}$, respectively, are the biggest ones. In 2005 the Turkish General Directorate of Mineral Research and Exploration (MTA) began a new coal exploration campaign in several basins. Within this context MTA explored several Neogene basins and discovered few new coal deposits. As a result, the total lignite reserves increased up to $12 \mathrm{Gt}$ (Besbelli, 2009; MTA, 2010).

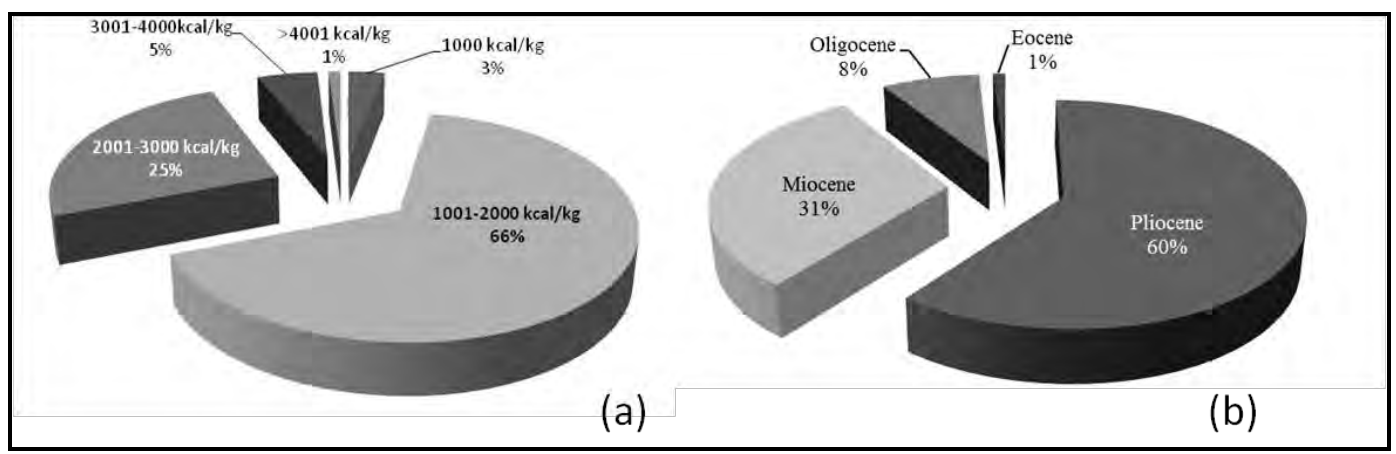

Figure 4 - (a) Distribution of Turkish lignite by calorific value (from EÜAŞ, 2011) and (b) Distribution of Cenozoic coal reserves by age (from Besbelli, 2009) 


\section{Coal Production and Consumption}

The annual total coal production in Turkey is around $78 \mathrm{Mt}$ (TKK, 2009; TKI, 2010; EÜAŞ, 2011). The coal-fired thermal power plants (11,900 MW installed capacity) contribute to $24 \%$ in Turkey's installed capacity (total of 52,911 MW) and the electricity generation (66 TWh) amounts to $29 \%$ of the total 229.4 TWh (Tables 1, 2; EÜAŞ, 2011).

Bituminous coals are only mined at Zonguldak coalfield, NW Turkey. The annual production is around 2.9 Mt (Ersoy, 2003; TKK, 2009), 80\% of which are generally directed to the iron and steel industry. Despite the low reserves, Zonguldak field mainly contains high quality and lowsulphur coking coal (Karayiğit et al., 1998). The Çatalağzı Power Plant in Zonguldak consumes bituminous coal generating 2004 GWh per year (Table 3; EÜAŞ, 2011). In addition, the Middle Miocene Gökler-Gediz deposits include coking coal with very high sulphur contents, being suitable for the cement industry (Karayiğit and Whateley, 1997). Bituminous coal utilisation for domestic heating is very low (Ersoy, 2003).

The lignite and subbituminous coal reserves contribute to $90 \%$ of the total reserves; however, they display low calorific values $(<2500 \mathrm{kcal} / \mathrm{kg}$ ), high moisture, ash yield and total sulphur content (İnaner and Nakoman, 1997; Karayiğit et al., 2000; Tuncali et al., 2002; Palmer et al., 2004; Anaç, 2009). These properties make lignite suitable for power generation only. The annual low-rank coal production is around $67 \mathrm{Mt}$ (TKI, 2010) mainly combusted in power plants $(76 \%$ of total lignite production; Anaç, 2009). Lignite-fired power plants generate $38.87 \mathrm{TWh}$ per year (Table 3; EÜAŞ, 2011). Domestic heating is a secondary application of lignite (14\% of annual production) mainly exploited from the Soma/Manisa and Tunçbilek/Kütahya and some other small deposits such as these of Ispir, Erciş/Erzurum and Refahiye/Erzican (İnaner and Nakoman, 1997; Anaç, 2009). Domestic heating is also supported by imported lignite, whereas c. 3 Mt of domestic lignite is consumed by cement, ceramic and food industry (TKI, 2010).

Table 3 - Installed capacity and generation of the major coal-fired thermal power plants in Turkey and the feeding deposits (modified from Karayiğit et al., 2000; EÜAŞ, 2011)

\begin{tabular}{|c|c|c|c|c|}
\hline Thermal power-plant & Fuel Type & $\begin{array}{c}\text { Installed } \\
\text { Capacity } \\
\text { (MW) }\end{array}$ & $\begin{array}{c}\text { Power } \\
\text { Generation } \\
(\mathbf{G W h})\end{array}$ & Feeding Deposit/Age \\
\hline Çatalağz1 & Bitumimous coal & 300 & 2,004 & Zonguldak/Carboniferous \\
\hline Afşin-Elbistan A & Lignite & 1,335 & 3,251 & Afşin-Elbistan/Pliocene \\
\hline Afşin-Elbistan B & Lignite & 1,440 & 5,733 & Af̧̧in-Elbistan/Pliocene \\
\hline Canakkale 18 Mart & Subbitum. coal & 320 & 2,127 & Çan/Miocene \\
\hline Orhaneli & Lignite & 210 & 1,300 & Orhaneli/Miocene \\
\hline Seyitömer & Lignite & 600 & 3,896 & Seyitömer/Miocene \\
\hline Tunçbilek & Subbitum. coal & 365 & 1,791 & Tunçbilek/Miocene \\
\hline Kangal & Lignite & 457 & 2,491 & Kangal/Pliocene \\
\hline Soma A+B & Subbitum. coal & 1,034 & 5,020 & Soma/Miocene \\
\hline Kemerköy & Lignite & 630 & 2,503 & Hüsamlar/Miocene \\
\hline Yeniköy & Lignite & 420 & 2,611 & Yeniköy/Miocene \\
\hline Yatağan & Lignite & 630 & 3,274 & Yatağan/Miocene \\
\hline Çayırhan & Lignite & 620 & 5,000 & Beypazar/Miocene \\
\hline Total & & $\mathbf{8 , 3 6 1}$ & $\mathbf{4 1 , 0 0 1}$ & \\
\hline
\end{tabular}


Of course, the environmental impacts from coal mining (dust, water-table lowering and contamination, landslides, acid drainage, etc.), washing (acid leaching, contamination) and combustion (emissions of trace elements and gasses such as $\mathrm{CO}_{2}, \mathrm{NO}_{\mathrm{x}}$ and $\mathrm{SO}_{\mathrm{x}}$; the latter due to the generally high sulphur contents of the Turkish coals) constitute severe disadvantages, which can be reduced by applying proper exploitation techniques.

\section{Conclusion}

Tectonics is the most important factor controlling the formation of coal-bearing basins in Turkey. Cenozoic era was favourable for coal formation. Eocene coal deposits display low reserves but better quality than the younger Miocence-Pliocene ones. The latter deposits include larger reserves but their calorific values are lower than these of the Eocene coals. Mesozoic era did not favoured coal formation, whereas most Palaeozoic coal deposits (besides this of Zonguldak) are not mineable.

Recent estimations reveal an increasing trend in the energy demand of Turkey. Electricity generation is mainly based on hydropower and fossil fuels. Although the share of imported energy resources is currently higher than this of domestic ones, domestic coal will decrease dependence on imported fuels. Total coal reserves of Turkey amount to around $12 \mathrm{Gt}$ in total; they mostly consist of lignite with low calorific value. Low-rank coal (lignite and sub-bituminous) mining is higher than this of bituminous coal that derives from one coal deposit only, and goes to thermal power plants; household and industrial utilisation is limited.

Low-rank coals are of great importance and their exploration and exploitation are more advanced than these of other domestic energy sources. Turkey hosts large coal reserves mineable at low cost. Thus coal, along with renewable energy sources, might gain more importance in the future supporting the increasing energy demand of the country.

\section{References}

Akgün F. and Akyol E. 1992. Palynology and paleoecology of the coals in Amasra-Bartin Carboniferous basin, Turkish Journal of Earth Science, 1(1), 49-56 (in Turkish with English abstract).

Akgün F. and Akyol E. 1999. Palynostratigraphy of the coal-bearing Neogene deposits graben in Büyük Menderes Western Anatolia, Geobios, 32(3), 367-383.

Akgün F. and Sözbilir H. 2001. A palynostratigraphic approach to the SW Anatolian molasse basin: Kale-Tavas molasse and Denizli molasse, Geodinamica Acta, 14(1-3), 71-93.

Akgün F. and Akkiraz M.S. 2005. Palynology and age of the Early Oligocene units in ÇardakTokça Basin, Southwest Anatolia: Paleoecological implications, Geobios, 38(3), 283-299.

Akkiraz M.S., Kayseri M.S. and Akgün F. 2008. Palaeoecology of coal-bearing Eocene sediments in Central Anatolia (Turkey) based on quantitative palynological data, Turkish Journal of Earth Sciences, 17(2), 317-360.

Akkiraz M.S., Akgün F., Utescher T., Bruch A.A. and Mosbrugger V. 2011. Precipitation gradients during the Miocene in Western and Central Turkey as quantified from pollen data, Palaeogeography, Palaeoclimatology, Palaeoecology, 304(3-4), 276-290.

Anaç S. 2009. Present situation of coal in energy policy of Turkey and Turkish coal industry, Proc. of $26^{\text {th }}$ Annual International Pittsburgh Coal Conference, Pittsburgh, 20-23 Sept.

Besbelli B. 2009. Coal Potential of Turkey and the Importance of Coal in Electricity Supply, Proc. of the $62^{\text {th }}$ Geological Congress of Turkey, Ankara, 16-22April.

Biresselioğlu M.E., Demir M.H. and Kandemir C. 2012. Modelling Turkey's future LNG supply security strategy, Energy Policy, 46, 144-152.

Bozkurt E. and Sözbilir H. 2004. Tectonic evolution of the Gediz Graben: Field evidence for an episodic, two-stage extension in western Turkey, Geological Magazine, 141(1), 63-79.

$\underline{\text { XLVII, No } 3-2118}$ 
Can E., Kuşçu Ş., and Mekik Ç. 2012. Determination of underground mining induced displacements using GPS observations in Zonguldak-Kozlu Hard Coal Basin, International Journal of Coal Geology, 89, 62-69.

Demirbaş A. 2006. Turkey's Renewable Energy Policy, Energy Sources, Part A, 28, 657-665.

Ediger V.S. 1990. Paleopalynology of coal-bearing Miocene sedimentary rocks associate with volcanics of the Biga Peninsula (NW Turkey) and effect of volcanism on vegetation, Neues Jahrbuch für Geologie, Abh., 180, 259-277.

Ekşi I.H., Şentürk M. and Yıldırım H.S. 2012. Sensitivity of Stock Market Indices to Oil Prices: Evidence from Manufacturing Sub-Sectors in Turkey, Panoeconomicus, 59(4), 463-474.

Electricity Generation Co. Inc. (EÜAŞ) 2004. Annual Report of 2004.

Electricity Generation Co. Inc. (EÜAŞ) 2011. Annual Report of 2011.

Ercan T., Satır M., Sevin D. and Türkercan A. 1996. Interpretation of the new radiometric age determinations from the tertiary and quaternary volcanic rocks in Western Anatolia, Mineral Res. Expl. Bull. Turkey, 119, 103-112 (in Turkish with English abstract).

Erdoğan B., Akay E. and Uğur M.S. 1996. Geology of the Yozgat region and evolution of the collisional Çankırı Basin, International Geology Review, 38(9), 788-806.

Ersoy M. 2003. Current status of Turkish lignite sector. UNECE Ad Hoc Meeting of Experts on Coal in Sustainable Development, Geneva, Switzerland.

Gold O. and Lüttig G. 1972. Elbistan: Erfolg einer Untersuchung der Türkei auf Braunkohle mit Mitteln der Deutschen Technischen Hilfe (Känozoikum und Braunkohle der Türkei 7), Braunkohle, 24(8), 253-268.

Gökmen V., Memikoğlu O., Dağlı M., Öz D. and Tuncalı E. 1993. Inventory of Turkish lignites. MTA Publication, Ankara, 356 pp. (in Turkish).

Görür N., Akkök R., Sakınç M., Ünalan G. and Yaltırak C. 1997, Tertiary basin Turkey and their coal potentials. In Önal, G., Kurşun, İ. and Yazıcı, H. (eds), Defining Targets and Methods on Turkish Coal Explorations, 8-37 (in Turkish).

İnaner H. and Nakoman E. 1997. Turkish lignite deposits. In Gayer, R., Pesek, J. (eds), European Coal Geology and Technology, Geol. Soc. Spec. Pub., 125, 77-99.

İnaner H. and Nakoman E. 2004. Resources, quality and economic importance of solid fossil fuels in Turkey, Geologica Belgica, 7(3-4), 245-250.

Karayiğit A.İ. and Whateley M.K.G. 1997. Chemical characteristics, mineralogical composition and rank of high sulphur coking coals of Middle Miocene age in the Gökler coalfield, Gediz, Turkey. In Gayer, R., Pesek, J. (eds), European Coal Geology and Technology, Geol. Soc. Spec. Pub., 125, 115-130.

Karayiğit A.İ., Gayer R.A. and Demirel I.H. 1998. Coal rank and petrography of Upper Carboniferous seams in the Amasra coalfield, Turkey, International Journal of Coal Geology, 36, 277-294.

Karayiğit A.I., Gayer R.A., Querol X. and Onacak T. 2000. Contents of major and trace elements in feed coals from Turkish coal-fired power plants, International Journal of Coal Geology, $44,169-184$

Karayiğit A.I. and Querol X. 2002. Mineralogy and elemental contents of the Şırnak Asphaltite, Southeast Turkey, Energy Sources, 24, 703-713.

Kayseri M.S. and Akgün F. 2008. Palynostratigraphic, palaeovegetational and palaeoclimatic investigations on the Miocene deposits in Central Anatolia (Çorum region and Sivas Basin), Turkish Journal of Earth Sciences, 17(2), 361-403.

Kelling G., Robertson A. and van Buchem F. 2005. Cenozoic sedimentary basins of southern Turkey: an introduction, Sedimentary Geology, 173, 1-13.

Kıncay O. and Öztürk R. 2003. Thermal Power Plants in Turkey, Energy Sources, 25, 135-151.

Kocaoğlu Y. 2009. Study on the electricity generation cost. Proc. of the TMMOB Energy Symposium, Ankara, 17-19December (in Turkish).

Kok M.V. 2010. Geological considerations for the economic evaluation of Turkish oil shale deposits and their combustion-pyrolysis behaviour, Energy Sources, Part A, 32, 32-335. 
Korkmaz S. and Kara-Gülbay R. 2007. Organic geochemical characteristics and depositional environments of the Jurassic coals in the eastern Taurus of Southern Turkey, International Journal of Coal Geology, 70, 292-304.

Lüttig G. 1968. Stand und Möglichkeiten der Braunkohlen-Prospektion in der Türkei, Geologisches Jahrbuch, 85, 585-604 (in German with English abstract).

Lynch R. 2003. An energy overview of the Republic of Turkey. U.S. Department of Energy. Available online at: http://www.fe.doe.gov/international/turkover.html.

Maden Tetkik ve Arama Genel Müdürlüğü (MTA) 2010. Inventory of Turkish lignites. MTA Publication, Ankara, 202 pp. (in Turkish).

Mann U., Korkmaz S., Boreham C.J., Hertle M., Radke M. and Wilkes H. 1998. Regional geology, depositional environment and maturity of organic matter of Early to Middle Jurassic coals, coaly shales, shales and claystones from the Eastern Pontides, NE Turkey, International Journal of Coal Geology, 37, 257-268.

Melikoğlu M. 2013. Vision 2023: Feasibility analysis of Turkey's renewable energy projection, Renewable Energy, 50, 570-575.

Ministry of Energy and Natural Resources (MENR) 2004. Energy Report of Turkey, Ankara.

Okay A. I., Şengör A.M.C. and Görür N. 1994. Kinematics history of the opening of the Black Sea and its effect on the surrounding regions, Geology, 22, 267-270.

Palmer C.A., Tuncali E., Denen K.O., Coburun T.C. and Finkelman R.B. 2009. Characterization of Turkish coals: a nationwide perspective, International Journal of Coal Geology, 60, 85115.

Parkmaden 2012. Konya-Ilgin project. Available online at: http://www.cinergroup.com.tr/energy.

Salman M. 2010. Lignite possibilities of Ereğli-Ayranc1-Karapınar (Konya) region and determination of its economic value. MSc. Thesis, Çukurova University (unpublished).

Sözbilir H. 2005. Oligo-Miocene extension in the Lycian orogen: Evidence from the Lycian molasse basin, SW Turkey, Geodinamica Acta, 18(3-4), 255-282.

Şengör A.M.C. and Yilmaz Y. 1981. Tethyan evolution of Turkey: A plate tectonic approach, Tectonophysics, 75, 181-241.

Şengör A.M.C., Görür N. and Şaroğlu F. 1984. Strike-slip faulting and related basin formation in zones of tectonic escape: Turkey as a case study, In Biddle K.T., Christie-Blick N. (eds.), Strike-slip Faulting and Basin Formation, Soc. Econ. Paleontol. Mineral. Sp. Pub., 37, 227264.

Şengüler İ. 2010. Lignite explorations in Turkey: New projects and new reserves. Proc. of the $27^{\text {th }}$ Annual International Pittsburgh Coal Conference, October 11-14, 2010, İstanbul.

Taşman, C.E., 1950. Stratigraphic distribution of bituminous appearing in Turkey, Mineral Res. Expl. Bull. Turkey, 40, 41-49 (in Turkish with English abstract).

Toprak S. 2009. Petrographic properties of major coal seams in Turkey and their formation, International Journal of Coal Geology, 78, 263-275.

Tuncalı E., Çiftci B., Yavuz N., Toprak S., Köker A., Gencer Z., Ayçık H. and Pahin N. 2002. Chemical and Technological Properties of Turkish Tertiary Coals, MTA Publication, Ankara, $401 \mathrm{pp}$.

Turkish Coal Enterprise (TKI) 2010. Annual Report of 2010, Ankara, 53 pp.

Turkish Hard-Coal Enterprise (TKK) 2009. Annual Report of 2008, Zonguldak, 103 pp.

Turkish Petroleum Corporation (TPAO) 2011. Annual Report of Turkish Petroleum and Natural Gas Sector of Turkey in 2011, Ankara, 23 pp.

Ünalan G. 2003. General evaluation of energy resources of Turkey, Geological Engineering Journal, 27 (1), 17-44 (in Turkish with English abstract).

Ünalan G. 2010. Coal Geology, MTA Publication, 41, Ankara, 556 pp.

Yilmaz A.O. and Uslu T. 2007. Energy policies of Turkey during the period 1923-2003, Energy Policy, 35, 258-264. 